\title{
IBA AND MICROCUTTING COLLECTIONS IN THE MICROPROPAGATION OF Eucalyptus spp HYBRID CLONES. ${ }^{1}$
}

Ricardo Gallo ${ }^{2 *}$, Aloisio Xavier ${ }^{3}$, Luciana Coelho de Moura $^{4}$, Brener de Almeida Oliveira ${ }^{5}$, Heloisa Rocha do Nascimento ${ }^{6}$ and Wagner Campos Otoni ${ }^{7}$

\footnotetext{
${ }^{1}$ Received on 08.08.2014 accepted for publication on 26.09.2017.

${ }^{2}$ Universidade Federal de Viçosa, Programa de Pós-Graduação em Ciência Florestal,Viçosa, Minas Gerais, Brasil. E-mail: <gallo.florestal@gmail.com>.

${ }^{3}$ Universidade Federal de Viçosa, Departamento de Engenharia Florestal, Viçosa, MG, Brasil . E-mail: <xavier@ufv.br>.

${ }^{4}$ Universidade Federal de Viçosa, Doutorado em Ciência Florestal, Viçosa, MG, Brasil.E-mail<lucianacm2005@yahoo.com.br>.

${ }^{5}$ Universidade Federal de Viçosa, Graduado em Ciência Florestal, Viçosa, MG, Brasil. E-mail: < b.oliveiraefl@gmail.com>.

${ }^{6}$ Universidade Federal de Viçosa, Programa de Pós-Graduação em Fitotecnia, Viçosa, MG, Brasil. E-mail: < helornasc@gmail.com>. ${ }^{7}$ Universidade Federal de Viçosa, Departamento de Biologia Vegetal, Viçosa, MG, Brasil. E-mail: <wcotoni@gmail.com>.

*Corresponding author.
}

\begin{abstract}
This study aims to evaluate the effect of IBA concentrations and microcuttings successive collections in the micropropagation of Eucalyptus grandis $\mathrm{x}$ E. urophylla and Eucalyptus urophylla $\mathrm{x}$ E. globulus clones. Clumps containing six to eight buds of clones established in vitro were transferred to a 250 $\mathrm{mL}$ glass flask in JADS semisolid medium. Successive collections were performed every 20 days for Eucalyptus grandis $\mathrm{x}$ E. urophylla clone and every 30 days for Eucalyptus urophylla $x$ E. globulus clone. The following variables were evaluated under in vitro conditions: number of shoots $>0.5 \mathrm{~cm}$, number of microcuttings $>$ $2 \mathrm{~cm}$, length of the longest microcutting, and shoots vigor. Under ex vitro conditions, in the greenhouse and shade house, the following variables were evaluated: seedling height, percentage of survival, stem diameter, percentage of root observed at the lower end of the tube, and seedling vigor. In full sun (ex vitro), the following variables were analyzed: seedling height, stem diameter, survival, number of roots, root volume, seedling vigor, and shoot and root dry matter. Good in vitro microcuttings productivity was observed over the successive collections. IBA levels were adjusted for each clone, ranging from 0.25 to $0.50 \mathrm{mg} \mathrm{L}^{-1}$ for Eucalyptus grandis $\mathrm{x}$ E. urophylla clone, and from 0.75 to $1.0 \mathrm{mg} \mathrm{L}^{-1}$ for Eucalyptus urophylla $\mathrm{x}$ E. globulus clone. IBA concentrations led to residual effects under ex vitro conditions, providing good rooting and survival for Eucalyptus grandis $\mathrm{x}$ E. urophylla and Eucalyptus urophylla $\mathrm{x}$ E. globulus clones at IBA concentrations between 0.25 and 0.50 $\mathrm{mg} \mathrm{L}^{-1}$ and between 0.50 and $1.0 \mathrm{mg} \mathrm{L}^{-1}$, respectively.
\end{abstract}

Keywords: Cloning; In vitro propagation; Vegetative propagation.

\section{AIB E COLETAS DE MICROESTACAS NA MICROPROPAGAÇÃO DE CLONES HÍBRIDOS DE Eucalyptus spp.}

\begin{abstract}
RESUMO-O presente trabalho tem como objetivo avaliar o efeito de doses de AIB e de coletas sucessivas de microestacas na micropropagação de clones de Eucalyptus grandis $x$ E. urophylla e Eucalyptus urophylla $x$ E. globulus. Tufos contendo de seis a oito gemas dos clones in vitro, foram transferidos para frascos de vidro - $250 \mathrm{~mL}$, em meio semissólido JADS, sendo feitas coletas a cada 20 dias para o clone Eucalyptus grandis $x$ E. urophylla e a cada 30 dias para o Eucalyptus urophylla $x$ E. globulus. Nas condições in vitro, foram avaliados: número de brotos $>0,5 \mathrm{~cm}$, número de microestacas $>2 \mathrm{~cm}$, comprimento da maior microestaca e vigor dos brotos. Nas condições ex vitro, na casa de vegetação e casa de sombra, foram avaliados: altura da muda, sobrevivência, diâmetro do colo, porcentagem de emissão de raiz na extremidade inferior do tubete, vigor das mudas. Em pleno sol (ex vitro), foram avaliados: altura da muda, sobrevivência, diâmetro do colo, número de raízes, volume de raiz, vigor das mudas, e matéria seca da parte aérea e da raiz. Observou-se
\end{abstract}


boa produtividade de microestacas in vitro no decorrer das coletas, sendo ajustados níveis de AIB para cada clone, variando de 0,25 a 0,50 $\mathrm{mg} \mathrm{L}^{-1}$ para o clone Eucalyptus grandis $x$ E. urophylla e de 0,75 a $1,0 \mathrm{mg}$ $L^{-1}$ para o clone Eucalyptus urophylla $x$ E. globulus. Nas condições ex vitro, a dosagem de AIB apresentou efeito residual, proporcionando bom enraizamento e sobrevivência, entre 0,25 a $0,50 \mathrm{mg} \mathrm{L}^{-1}$ de AIB para o clone Eucalyptus grandis $x$ E. urophylla e 0,50 a $1,0 \mathrm{mg} L^{-1}$ para o clone Eucalyptus urophylla $x$ E. globulus.

Palavras-chave: Clonagem; Propagação in vitro; Propagação vegetativa.

\section{INTRODUCTION}

The successful productivity of Eucalyptus plantations in Brazil is a result of the combination of several factors, such as the well-established clonal forestry programs, the constant development of genetic improvement strategies, the production of specific hybrids, the selection of elite clones, and the improvement of clonal propagation technologies (Ferrari et al., 2004; Xavier et al., 2013).

Micropropagation is a clonal technique that produces microcuttings and provides countless advantages to the production process of Eucalyptus seedlings, such as faster mass propagation of clones; greater nutritional, environmental, and phytosanitary control; and longer storage periods; besides retention of hybrid vigor and the possibility of transport over long distances without damaging the material (Bisht et al., 1999; Xavier et al., 2013).

In addition, microcuttings production by micropropagation improves the cloning process due to the rejuvenation and reinvigoration technique used as a mechanism to overcome rooting problems of the cuttings, which is mainly observed in the rescue of adult trees (Joshi et al., 2003; Xavier et al., 2013).

Specific innovations have been proposed for the application of large-scale micropropagation technologies in Eucalyptus (Xavier et al., 2013), such as the manipulation of the in vitro atmosphere and/or environment (e.g., photoautotrophic propagation) (Kozai, 2010); the use of temporary immersion and liquid medium bioreactors (Oliveira et al., 2011, 2014); the replacement of the semisolid medium with alternative substrates (Kirdmanee, et al., 1995); the automation and mechanization of systems operations (Penchel et al., 2007); and the use of in vitro microclonal hedge.

Several factor can influence the productivity of the traditional miniclonal hedge, such as climatic variables, the genetic material, the production system (Cunha et al., 2005), the mineral nutrition (Cunha et al., 2009a),

Revista Árvore. 2017;41(6):e410605 the management of miniclonal hedge seedlings (Mafia et al., 2005), among others. Cunha et al. (2009b) concluded that the increase in temperature favors the production of minicuttings in eucalyptus miniclonal hedge, regardless of the miniclonal hedge type.

The major advantage of transferring the miniclonal hedge from ex vitro to in vitro environment is the greater control of climatic variables, such as low temperatures, besides the in vitro elimination of pests and diseases. Thus, the existence of efficient micropropagation protocols for Eucalyptus would enable the use of in vitro microclonal hedge and make the microcuttings available to the forest industry (Xavier et al., 2013).

The knowledge of the use of auxins is fundamental for the establishment of efficient protocols. This fact is because these growth regulators are directly related to several physiological processes, such as activation of cambium cells, apical dominance, plant growth promotion, lateral and adventitious root formation, foliar abscision, floral buds and fruits development, and induction of vascular differentiation (Bresinsky et al., 2012; Kerbauy, 2012; Taiz and Zeiger, 2013).

IBA (3-indole butyric acid) is widely used in in vitro and ex vitro propagation processes as this auxin does not damage explants. However, the concentration to be applied must be tested for each species and propagule (Titon et al., 2003a; Iacona and Muleo, 2010).

Studies have reported the need for using IBA for rooting in the micropropagation of several morphological processes, such as: rooting in Oncidium baueri (Camargo et al., 2015); increase in number and length of roots in nodal segments of Campomanesia adamantium (Rossato et al., 2015); in vitro elongation of hybrid clones of Eucalyptus globulus (Oliveira et al., 2016); and ex vitro acclimatization and rooting of Ilex paraguariensis microcuttings (Tronco et al., 2015).

The in vitro environment enables the production of microcuttings. The knowledge of the number of collections or production time in this system is crucial 
for the establishment of an in vitro microclonal hedge. The information on the the number of collections or production can provide the amount of microcutting that a clump of shoot can produce in a given time and and culture medium, providing practical benefits to the implantation of in vitro microclonal hedge.

The objective of the present work was to evaluate the effect concentrations of IBA and successive collections of microcutting on clumps of shoots in multiplication in the micropropagation of clones of Eucalyptus grandis x E. urophylla and Eucalyptus urophylla $\mathrm{x}$ E. globulus.

\section{MATERIALAND METHODS}

\subsection{Plant material and in vitro cultivation conditions}

The experiments were conducted at the Tissue Culture Laboratory II of the Institute of Applied Biotechnology for Agriculture (BIOAGRO), at the Federal University of Viçosa, located in the municipality of Viçosa/MG.

The material used in this work resulted from the multiplication by micropropagation of Eucalyptus grandis $\mathrm{x}$ E. urophylla and Eucalyptus urophylla $\mathrm{x}$ E. globulus clones, with 25 and 72 subcultures, respectively. Shoots originated from clumps containing six to eight differentiated buds were cultivated in test tubes containing $10 \mathrm{~mL}$ JADS culture medium (Correia et al., 1995), added with $30 \mathrm{~g} \mathrm{~L}^{-1}$ of sucrose (Vetec ${ }^{\mathrm{TM}}$ ), $100 \mathrm{mg} \mathrm{L}^{-1}$ ofmyo-inositol (Sigma ${ }^{\mathrm{TM}}$ ), $800 \mathrm{mg} \mathrm{L}^{-1}$ of PVP30 (polyvinylpyrrolidone - Vetec ${ }^{\mathrm{TM}}$ ), $0.5 \mathrm{mg} \mathrm{L}^{-1}$ of BAP $\left(6\right.$ - benzylaminopurine - Sigma $\left.^{\mathrm{TM}}\right), 0.01 \mathrm{mg} \mathrm{L}^{-1}$ of NAA (naphthaleneacetic acid - Sigma ${ }^{\mathrm{TM}}$ ), and $7 \mathrm{~g} \mathrm{~L}^{-1}$ of agar $\left(\mathrm{Merck}^{\mathrm{TM}}\right)$.

Subsequently, clumps were transferred to test tubes with JADS culture medium added with $0.3 \mathrm{mg} \mathrm{L}^{-1}$ of BAP. The culture medium was adjusted to $\mathrm{pH} 5.8$ and autoclaved in $1.5 \mathrm{~atm}$ pressure, at $121^{\circ} \mathrm{C}$, for 20 minutes.

Cultures were maintained in a growth room at 25 $\pm 2{ }^{\circ} \mathrm{C}$, for $16 \mathrm{~h}$ photoperiod, and $33 \mathrm{ìmol} \mathrm{m}^{-2} \mathrm{~s}^{-1}$ irradiances (quantified by the LI-COR ${ }^{\mathrm{TM}}$ radiometer, LI-250A Light Meter), provided by two tubular fluorescent lamps (Special Daylight, 40 W, Osram ${ }^{\mathrm{TM}}$, Brazil).

At 30 days after incubation in the culture medium, with BAP reduction, clumps of each clone were transferred to $250 \mathrm{~mL}$ glass flasks containing $40 \mathrm{~mL}$ of JADS culture medium, added with $30 \mathrm{~g} \mathrm{~L}^{-1}$ of sucrose, $100 \mathrm{mg} \mathrm{L}^{-1}$ of myo-inositol, $800 \mathrm{mg} \mathrm{L}^{-1}$ of PVP-30, $7 \mathrm{~g}$ $\mathrm{L}^{-1}$ of agar, $0.05 \mathrm{mg} \mathrm{L}^{-1}$ of BA, varying the concentrations of indole 3 butyric acid (IBA) (Sigma ${ }^{\mathrm{TM}}$ ) between 0.0 ; $0.25 ; 0.50$ and $1.00 \mathrm{mg} \mathrm{L}^{-1}$.

In each flask, four clumps containing six to eight shoots were inoculatedat the four IBA concentrations for each clone and maintained in a growth room with the same characteristics previously described. The experiment consisted of a completely randomized design, in a $5 \times 4$ factorial scheme, with five microcutting collections and four IBA concentrations $(0.0 ; 0.25 ; 0.50$; and 1.00 $\mathrm{mg} \mathrm{L}^{-1}$ ), with four replications; each plot contained four clumps of shoots.

\subsection{Microcuttings ex vitro rooting}

Experiments were conducted at the Research Center of the Forest Engineering Department of UFV.

Microcuttings $>2 \mathrm{~cm}$ from the clones and from treatments with IBA concentration under in vitro conditions were placed in Petri dishes containing two sheets of water-moistened filter paper and subsequently transferred to the nursery.

Microcuttings of each treatment (IBA concentrations) and clones (Eucalyptus grandis x E. urophylla and Eucalyptus urophylla $\mathrm{x}$ E. globulus) were planted in $55 \mathrm{~cm}^{3}$ plastic tubes containing commercial substrate (Tropstrato Vida Verde ${ }^{\mathrm{TM}}$ ) and vermiculite (medium particle size) at a ratio of $1: 1$, added with $5 \mathrm{~kg} \mathrm{~m}^{-3}$ of simple superphosphate (Heringer ${ }^{\mathrm{TM}}$ ), and placed in a greenhouse (at $20-30^{\circ} \mathrm{C}$ and relative humidity e" $80 \%$ ).

On the first ten days in the greenhouse, microcuttings were covered with Aluminet (50\%), at a distance of $20 \mathrm{~cm}$ from the tubes. At 20 days after greenhouse cultivation, microcuttings were transferred to a shade house, where they received topdressing by applying $2 \mathrm{~mL}$ of monoammonium phosphate (MAP) per seedling, at a concentration of $2 \mathrm{~g} \mathrm{~L}^{-1}$. Seedlings were maintained in the shade house $(50 \%)$ for ten days and then transferred to full sun, when they received $5 \mathrm{~mL}$ of the NPK formulation 20-5-20 (Heringer ${ }^{\mathrm{TM}}$ ) per seedling, at a concentration of $6 \mathrm{~g} \mathrm{~L}^{-1}$, remaining under this condition for another 30 days.

The experiment consisted of a completely randomized block design, with four IBA concentrations 
$\left(0.0,0.25,0.50\right.$, and $\left.1.00 \mathrm{mg} \mathrm{L}^{-1}\right)$ from the in vitro applications, in five blocks (collections), with a variable number of microcuttings, based on the in vitro production of each treatment.

\subsection{Experimental evaluations and data analysis}

Growth characteristics evaluation and microcuttings collection occurred every 20 days of in vitro cultivation for the Eucalyptus grandis $\mathrm{x}$ E. urophylla clone and every 30 days of in vitro cultivation for the Eucalyptus urophylla $\mathrm{x}$ E. globulus clone. Afterward, clumps of shoots were transferred to a new culture medium containing the same treatments. For both clones, five collections were performed, totaling 100 days of cultivation for Eucalyptus grandis x E. urophylla clone and 150 days for Eucalyptus urophylla x E. globulus clone.

Number of shoots $>0.5 \mathrm{~cm}$ per clump of shoots (NS $>0.5 \mathrm{~cm})$, number of microcuttings $>2 \mathrm{~cm}(\mathrm{NM}$ $>2 \mathrm{~cm}$ ), length of the longest microcutting $(\mathrm{cm})$ (LLM), and shoot vigor (SV) [based on a scale of grades ranging from 1 (Low), 2 (Intermediate), and 3 (High)] were analyzed on the day of each in vitro collection.

Under the ex vitro condition, at the moment of transfer from the greenhouse to the shade house, seedling height $(\mathrm{H}, \mathrm{cm})$, stem diameter (SD, $\mathrm{mm})$, percentage of survival (PS, \%), percentage of root observed at the lower end of the tube (PRT, \%), and seedling vigor (SEV) [based on a scale of grades ranging from 1 (Low), 2 (Intermediate), and 3 (High)] were evaluated. After 30 days in full sun, seedling height $(\mathrm{H}, \mathrm{cm})$, stem diameter (SD, $\mathrm{mm}$ ), percentage of survival (PS, \%), number of roots $(\mathrm{NR})$, root volume ( $\mathrm{RV}, \mathrm{cm} 3)$, and seedling vigor (SEV) [based on a grade scale ranging from 1 (Low), 2 (Intermediate), and 3 (High)], shoot dry matter (SDM, $\mathrm{g}$ ), and root dry matter (RDM, g) were evaluated.

Data were analyzed in the R software, version 3.2.4 (R Core Team, 2016), with the aid of the ExpDes package, version 1.1.2 (Ferreira et al., 2013). Percentage of survival and seedling height under ex vitro conditions did not present a normal distribution by the Shapiro-Wilk test at 5\% significance, and thus were transformed into $\operatorname{arcsen} \sqrt{x}$ and, respectively. Regression equations were generated for the variables that were significant by the analysis of variance.

\section{RESULTS}

\subsection{Eucalyptus grandis $\mathrm{x}$ E. urophylla clone}

Based on the results obtained in the in vitro evaluations, number of shoots $>0.5 \mathrm{~cm}$ (Figure 1A) showed a quadratic trend with the number of collections. An increase in the number of shoots was observed from the second collection, followed by stabilization. Number of shoots $>0.5 \mathrm{~cm}$ presented the quadratic trend (Figure 1E), with a decrease in production at the highest IBA concentration.

The production projection of microcutting $>2 \mathrm{~cm}$ (Figure 1B) tended to increase linearly. However, the maximum microcutting production occurred at the IBA concentration of $0.44 \mathrm{mg} \mathrm{L}^{-1}$ (Figure $1 \mathrm{~F}$ ).

The longest microcuttings were formed in the first and last collections (Figure 1C), increasing size from the fourth to the fifth collection. Conversely, shoot vigor over the collection presented a linear decrease (Figure 1D). The use of IBA concentrations for these variables had the same trend as that observed for the other evaluated characteristics, being the point that provides the longest microcutting, estimated in 0.54 $\mathrm{mg} \mathrm{L}^{-1}$ of IBA (Figure 1G). For shoot vigor, this point was estimated to be $0.45 \mathrm{mg} \mathrm{L}^{-1}$ of IBA (Figure $1 \mathrm{H}$ ).

The optimum range of IBA concentration for better results for shoot and microcutting production, as well as for size and vigor is from 0.25 to $0.50 \mathrm{mg} \mathrm{L}^{-1}$.

Ex vitro evaluations at the moment of transfer from the greenhouse to the shade house had the same results as those reported for the in vitro environment. The characteristics treated with IBA presented quadratic results with in vitro IBA concentrations of $0.25 \mathrm{mg}$ $\mathrm{L}^{-1}$ (Figure 2B), and higher percentage of root observed at the lower end of the tube (Figure 2C).

At the moment of transfer from the greenhouse to the shade house, IBA concentrations did not affect the characteristics evaluated in the seedlings. However, in the latst evaluation in full sun, treatments with IBA concentrations applied in vitro significantly influenced percentage of survival (PS, \%), number of roots (NR), shoot dry matter (SDM, g), root dry matter (RDM, g), and root volume $\left(\mathrm{RV}, \mathrm{cm}^{3}\right)$ (Figure $\left.2 \mathrm{D}-\mathrm{H}\right)$.

RV showed a decreasing linear trend in function of the in vitro IBA treatments. $\mathrm{RV}$ reduced at the highest IBA concentration (1.0 $\left.\mathrm{mg} \mathrm{L}^{-1}\right)$ (Figure 2D). The highest

Revista Árvore. 2017;41(6):e410605 

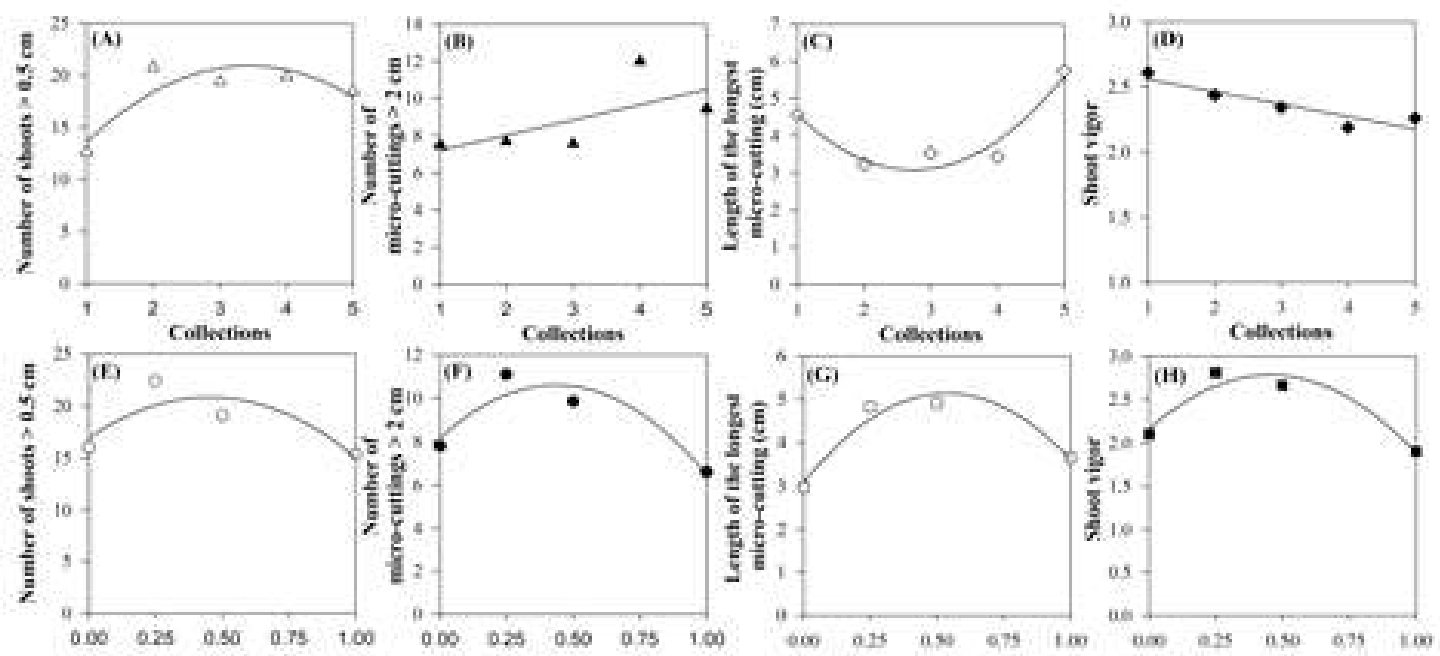

IBA $(m e)^{-1}$

IBA $\left(\operatorname{mog} \mathbf{L}^{-1}\right.$ )

$\operatorname{IBN}\left(\operatorname{me} \mathbf{L}^{-1}\right)$

$18 \times\left(m g L^{-1}\right)$

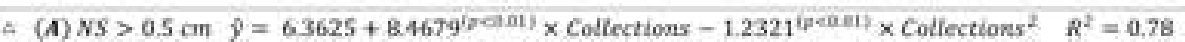

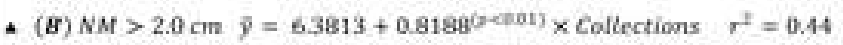

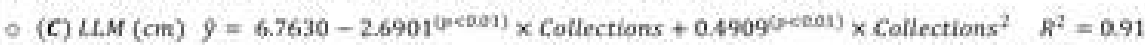

- (D) $S Y \quad p=2.6525-0.095^{(p-0001)} \times$ Collections $r^{2}=0.84$

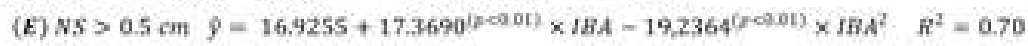

- $(F) N M>2.0 \mathrm{~cm} 9=8.1519+11.2765^{00001)} \times I B A-12.9455^{(0.001)} \times I B A^{2} \quad R^{2}=0.88$

(G) $\operatorname{LLM}(\mathrm{cm}) \hat{y}=3.0771+7.6551^{600013} \times 1 B A-7.1117^{(0.009)} \times 1 B A^{2} \quad R^{2}=0.95$

. (U) SV $y=2.1567+2.7533^{(06001)} \times\left(B A-3.0291^{(200001)} \times I B A^{2} \quad R^{2}=0.93\right.$

Figure 1 - Characteristics observed in the in vitro cultivation of Eucalyptus grandis $\mathrm{x}$ E. urophylla clone in function of successive collections. (A) Number of shoots $>0.5 \mathrm{~cm}$; (B) Number of micro-cuttings $>2 \mathrm{~cm}$; (C) Length of the longest micro-cutting $(\mathrm{cm})$; and (D) Shoot vigor; and in function of IBA concentrations $(0.0,0.25,0.5$ and $1.0 \mathrm{mg} \mathrm{L}^{-1}$ ). (E) Number of shoots $>0.5 \mathrm{~cm} ;$ (F) Number of micro-cuttings $>2 \mathrm{~cm}$; (G) Length of the longest micro-cutting $(\mathrm{cm})$; and $(\mathbf{H})$ Shoot vigor.

Figura 1 - Características observadas no cultivo in vitro do clone Eucalyptus grandis $x$ E. urophylla em função das coletas sucessivas. (A) Número de brotos $>0,5 \mathrm{~cm} ;$ (B) Número de microestacas $>2 \mathrm{~cm} ;(\boldsymbol{C})$ Comprimento da maior microestaca (cm); e (D) Vigor dos brotos; e em função das doses de AIB $\left(0,0 ; 0,25 ; 0,5\right.$ e 1,0 mg L $\left.L^{-1}\right)$. (E) Número de brotos $>0,5 \mathrm{~cm} ;(\boldsymbol{F})$ Número de microestacas $>2 \mathrm{~cm} ;(\boldsymbol{G})$ Comprimento da maior microestaca $(\mathrm{cm}) ; e(\boldsymbol{H})$ Vigor dos brotos.

values for PS (Figure 2E), NR (Figure 2F), and for SDM (Figure 2G) and RDM (Figure 2H) were observed at intermediate IBA concentrations $\left(0.25\right.$ and $\left.0.5 \mathrm{mg} \mathrm{L}^{-1}\right)$, with a quadratic response at the end of the full sun stage (60 days).

The use of IBA under in vitro conditions also provided residual effects in the ex vitro conditions, directly influencing seedlings quality. Seedling height, seedling vigor, and percentage of root observed at the lower end of the tube were significant at the moment of transfer from the greenhouse to the shade house. However, these characteristics are statistically similar at the other stages (shade house and full sun). Stem diameter did not present statistical difference with treatments application in any of the ex vitro environment.

In the greenhouse, Eucalyptus grandis $\mathrm{x} E$. urophylla clone had mean value of $85.2 \%$ microcuttings survival without the influence of IBA concentrations applied under in vitro conditions. At the moment of transfer from the greenhouse to the shade house, and without the influence of the in vitro concentrations, percentage of survival decreased (78.45\%). Conversely, after 60 days in full sun, microcuttings showed $77.8 \%$ survival under the influence of the IBA concentrations applied in the in vitro environment. The point of maximum survival was estimated using $0.52 \mathrm{mg} \mathrm{L}^{-1}$ IBA in the culture medium, under in vitro condition. 

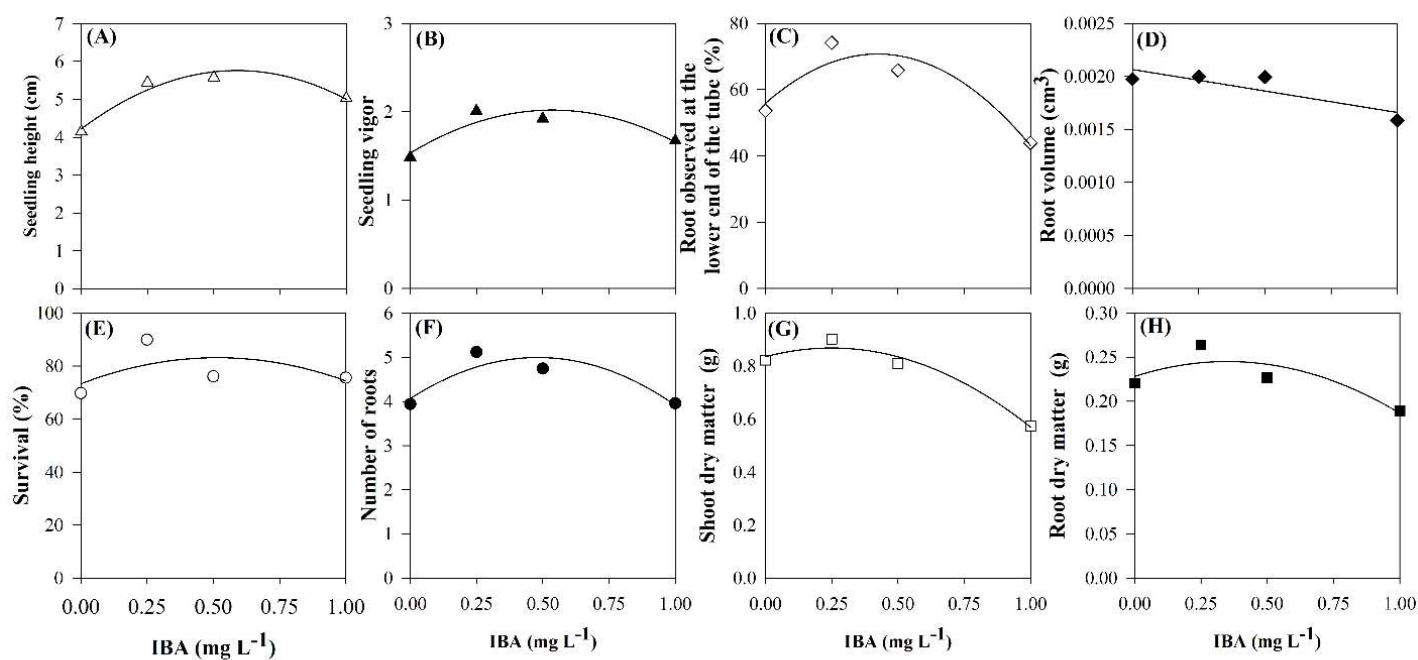

$\Delta(A) H(c m) \hat{y}=4.2186+5.2441^{(p<0.01)} \times I B A-4.4586^{(p<0.01)} \times I B A^{2} \quad R^{2}=0.95$

\(B) $S E V \quad \hat{y}=1.5308+1.8185^{(p<0.01)} \times I B A-1.6937^{(p<0.01)} \times I B A^{2} \quad R^{2}=0.84$

$\diamond(C) P R T(\%) \hat{y}=55.8513+70.3921^{(p=0.023)} \times 1 B A-83.0793^{(p<0.01)} \times 1 B A^{2} \quad R^{2}=0.89$

- (D) $R V\left(\mathrm{~cm}^{3}\right) \hat{y}=0.002065-0.000406^{(p=0.012)} \times I B A \quad r^{2}=0.74$

○(E) $P S(\%) \hat{y}=73.2840+38.3886^{(p=0.041)} \times I B A-37.2722^{(p=0.033)} \times 1 B A^{2} \quad R^{2}=0.31$

- $($ F $) N R \quad \hat{y}=4.0635+3.8676^{(p<0.01)} \times I B A-4.0180^{(p<0.01)} \times I B A^{2} \quad R^{2}=0.81$

$\square(G) S D M(g) \hat{y}=0.8352+0.2647^{(p=0.199)} \times I B A-0.5301^{(p<0.01)} \times I B A^{2} \quad R^{2}=0.97$

- $(\boldsymbol{H}) R D M(g) \hat{y}=0.2281+0.0965^{(p=0.13)} \times I B A-0.1380^{(p=0.021)} \times I B A^{2} \quad R^{2}=0.75$

Figure 2 - Characteristics observed at the moment of transfer from the greenhouse to the shade house (A) Seedling height (cm); (B) Seedling vigor; and (C) Roots observed at the lower end of the tube (\%); and characteristics observed in the seedling in full sun (D) Root volume $\left(\mathrm{cm}^{3}\right)$; (E) Percentage of survival (\%); (F) Number of roots; (G) Shoot dry matter $(\mathrm{g})$; and $(\mathbf{H})$ Root dry matter $(\mathrm{g})$. For E. urophylla $\mathrm{x}$ Eucalyptus grandis clone in function of IBA concentrations $\left(0.0,0.25,0.5\right.$ and $\left.1.0 \mathrm{mg} \mathrm{L}^{-1}\right)$.

Figura 2 - Características observadas na saída da casa de vegetação (A) Altura da muda (cm); (B) Vigor das mudas; $e(C)$ Raiz observada na extremidade inferior do tubete (\%); e características observadas em pleno sol em mudas (D) Volume de raiz ( $\left.\mathrm{cm}^{3}\right)$; (E) Porcentagem de sobrevivência (\%); (F) Número de raiz; (G) Massa seca da parte aérea (g); e (H) Massa seca da raiz (g). Para o clone Eucalyptus grandis $x$ E. urophylla em função das doses de $A I B\left(0,0 ; 0,25 ; 0,5\right.$ e $\left.1,0 \mathrm{mg} \mathrm{L}^{-1}\right)$.

\subsection{Eucalyptus urophylla $\times$ E. globulus clone}

The analysis of variance for Eucalyptus urophylla $\mathrm{x}$ E. globulus clones revealed interaction in the collection. IBA concentrations were significant for number of shoots $>0.5 \mathrm{~cm}(\mathrm{NS}>0.5 \mathrm{~cm})$ [with significance $(p=0.0102)$ ] and shoot vigor $(\mathrm{p}<0.01)$. For the number of microcuttings $>2 \mathrm{~cm}(\mathrm{NM}>2 \mathrm{~cm})$, the variables the variables were independent $(p<0.01)$. For length of the longest microcuttings (LLM), only the IBA concentrations were significant $(\mathrm{p}<0.01)$.

IBA concentrations for $\mathrm{NS}>0.5 \mathrm{~cm}$ in function of the collections (Figure $3 \mathrm{~A}$ ) showed a second-degree

Revista Árvore. 2017;41(6):e410605 polynomial behavior. From the first collection, all IBA concentrations followed an increasing trend; however, from the third to the fourth collection, the IBA concentrations of $0.0 ; 0.25$ and $0.5 \mathrm{mg} \mathrm{L}^{-1}$ tended to reduce shoot production. For the highest IBA concentration $\left(1.0 \mathrm{mg} \mathrm{L}^{-1}\right)$, this trend only occurred from the fourth to the fifth collection.

For shoot vigor (SV), the response was in function of the interaction between treatments, showing a significant $(\mathrm{p}<0.01)$ decreasing linear behavior for IBA concentrations of $0.25 ; 0.50$ and $1.00 \mathrm{mg} \mathrm{L}^{-1}$ in function 
of the collections (Figure 3B), with an evident decrease in vigor with the advance of the monthly collections.

Production of $\mathrm{NM}>2 \mathrm{~cm}$ increased in function of the successive collections (Figure 3C), and the IBA concentration of $0.65 \mathrm{mg} \mathrm{L}^{-1}$ was the optimum point
(Figure 3D). LLM presented increasing linear response in function of the IBA concentrations (Figure 3E).

Results obtained under ex vitro conditions indicated the effect of IBA concentrations applied in the in vitro environment, with differences in the evaluations performed in greenhouse, shade house, and in full sun.
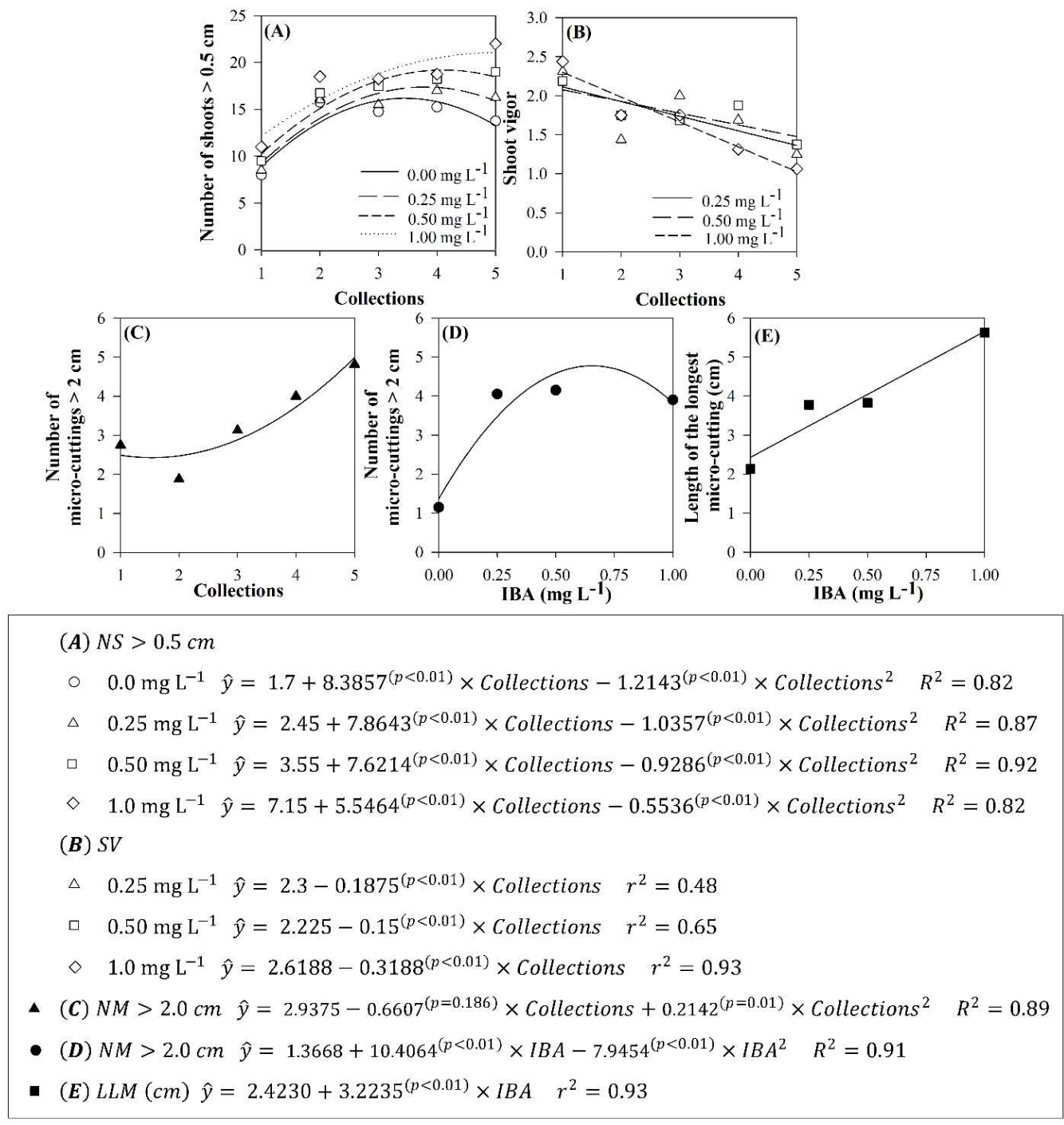

Figure 3 - Characteristics observed in in vitro cultivation of Eucalyptus urophylla $\times$ E. globulus clone in function of collections (every 30 days) and IBA concentrations $\left(0.0,0.25,0.5\right.$ and $\left.1.0 \mathrm{mg} \mathrm{L}^{-1}\right)$. (A) Number of shoots $>0.5 \mathrm{~cm}$; (B) Shoot vigor; (C) Number of micro-cuttings $>2 \mathrm{~cm}$ in function of the successive collections (D) and in function of the IBA concentrations; and (E) Length of the longest micro-cutting in function of the IBA concentrations.

Figura 3 - Características observadas no cultivo in vitro do clone de Eucalyptus urophylla $x$ E. globulus em função das coletas (a cada 30 dias) e doses de AIB (0,0;0,25;0,5 e 1,0 $\left.\mathrm{mg} \mathrm{L}^{-1}\right)$. (A) Número de brotos $>0,5 \mathrm{~cm} ;(\boldsymbol{B})$ Vigor dos brotos; (C) Número de microestacas $>2 \mathrm{~cm}$ em função das coletas sucessivas (D) e em função das doses de AIB; e (E) Comprimento da maior microestaca em função das doses de AIB. 
Seedling height at the moment of transfer from the greenhouse to the shade house had an increasing linear trend, and the highest IBA concentration (1.0 $\mathrm{mg} \mathrm{L}^{-1}$ ) was associated with higher mean values for seedling height (Figure 4A). However, under shade house and in full sun conditions, seedling height increased with the application of 0.91 and $0.80 \mathrm{mg} \mathrm{L}^{-1}$ of IBA, respectively.

Seedlings had a greater stem diameter in the ex vitro stages - greenhouse, shade house, and full sun - when the concentrations of 0.5 and $0.75 \mathrm{mg} \mathrm{L}^{-1}$ were used in the in vitro condition (Figure 4B). However,
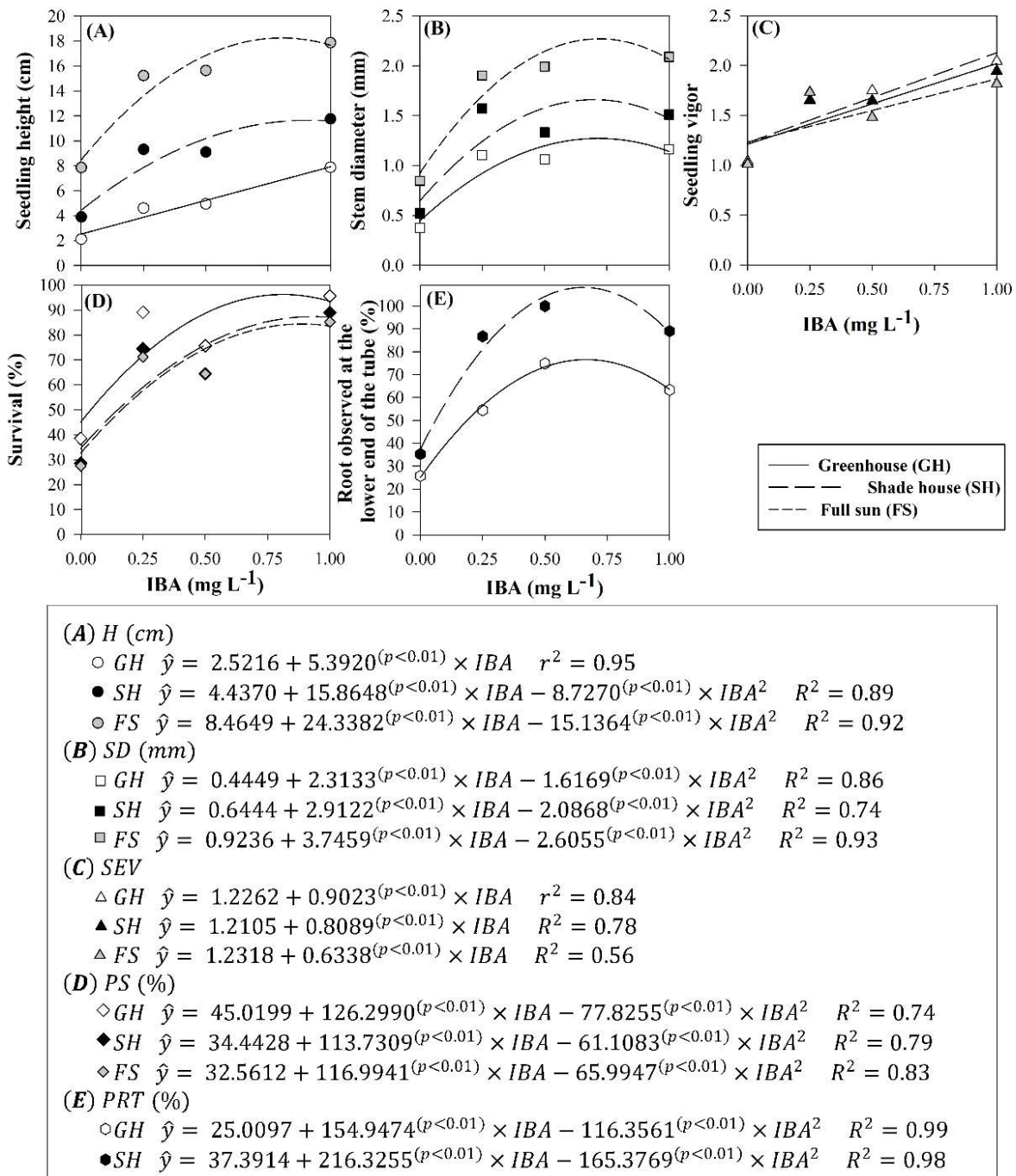

Figure 4 - Characteristics observed at the moment of transfer from the greenhouse $(\mathrm{GH})$ to the shade house (SH) and in full sun (FS) in seedlings of Eucalyptus urophylla $\times$ E. globulus clones in function of the IBA concentrations $\left(0.0,0.25,0.5\right.$ and $\left.1.0 \mathrm{mg} \mathrm{L}^{-1}\right)$. (A) Seedling height (cm); (B) stem diameter (mm); (C) Seedling vigor; (D) Percentage of survival (\%); and (E) Root observed at the lower end of the tube (\%).

Figura 4 - Características observadas na saída da Casa de vegetação (GH); Casa de sombra (SH) e Pleno sol (FS) em mudas do clone de Eucalyptus urophylla $x$ E. globulus em função das doses de AIB $\left(0,0 ; 0,25 ; 0,5\right.$ e 1,0 $\left.\mathrm{mg} \mathrm{L}^{-1}\right)$. (A) Altura da muda (cm); (B) Diâmetro do colo $(\mathrm{mm})$; (C) Vigor das mudas; (D) Porcentagem de sobrevivência (\%); e (E) Raiz observada na extremidade inferior do tubete (\%).

Revista Árvore. 2017;41(6):e410605 
for seedling vigor (SEV), higher values were observed at higher IBA concentrations used in the in vitro condition (Figure 4C).

The percentage of survival presented a quadratic trend for all the ex vitro stages, and the highest percentage was observed with the in vitro application of IBA concentration between 0.81 and $0.94 \mathrm{mg} \mathrm{L}^{-1}$ (Figure 4D). The percentage of root observed at the lower end of the tube presented a quadratic response to the regression equation. Consequently, this variable presented the highest values when the application of IBA ranged between 0.67 and $0.65 \mathrm{mg} \mathrm{L}^{-1}$ (Figure 4E) in the greenhouse and shade house, respectively.

NR (Figure 5A) and VR (Figure 5B) evaluated at the end of the full sun stage presented a quadratic trend in function of the IBA concentrations, with similar maximum points: for NR, the estimated point was 0.67 $\mathrm{mg} \mathrm{L}^{-1}$ of IBA; and for the VR, the estimated point was $0.70 \mathrm{mg} \mathrm{L}^{-1}$ of IBA.

SDM (Figure 5C) and RDM (Figure 5D) showed second-degree polynomial behavior in function of the IBA concentrations, with different maximum point of matter production: $0.75 \mathrm{mg} \mathrm{L}^{-1}$ for SDM and $0.92 \mathrm{mg}$ $\mathrm{L}^{-1}$ for $\mathrm{RDM}$.

Percentage of survival during microcuttings acclimatization at the moment of transfer from the greenhouse to the shade house presented a mean of $74.7 \%$, being influenced by the IBA concentrations applied in the in vitro environment. The highest percentage of survival was estimated in $96.3 \%$ with the IBA concentration of $0.81 \mathrm{mg} \mathrm{L}^{-1}$. At the moment of transfer from the shade house to the full sun, microcuttings survival $(64.2 \%)$ continued to be influenced by the concentrations that had been applied in the in vitro environment, with an optimal IBA concentration estimated at $0.70 \mathrm{mg} \mathrm{L}^{-1}$, which resulted in $84.0 \%$ microcuttings survival. In full sun, the mean value of microcuttings survival was $62.1 \%$, still influenced by residual IBA, presenting a maximum survival point estimated at $0.89 \mathrm{mg} \mathrm{L}^{-1}$ of IBA, leading to $84.0 \%$ microcuttings survival.

\section{DISCUSSION}

Under in vitro experimental conditions, the number of shoots of the Eucalyptus grandis x E. urophylla clone increased. Production decreased from the fourth collection, which was also observed in Eucalyptus
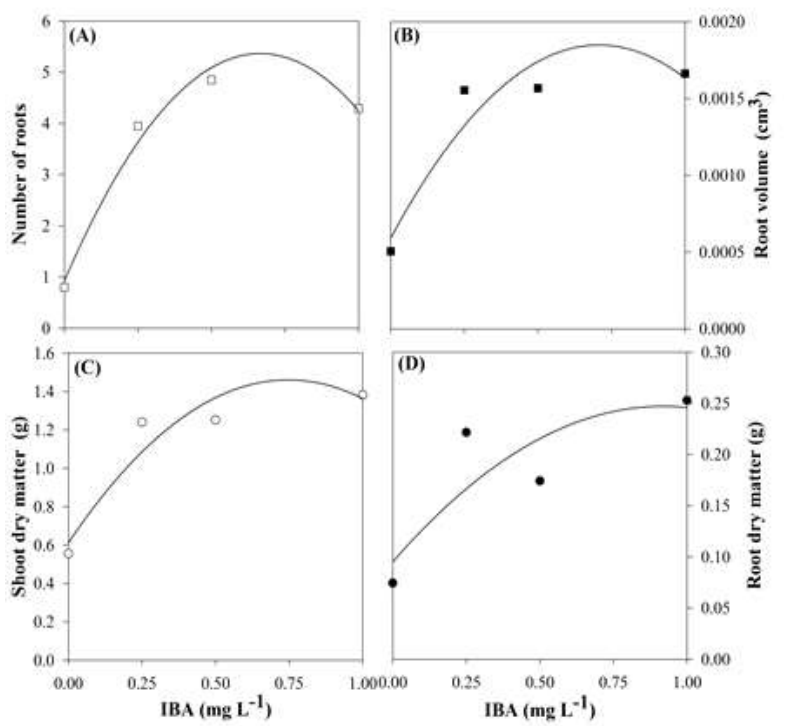

(A) $N R \hat{y}=0.9196+13.3500^{(p<0.01)} \times 1 B A-10.0212^{(p<001)} \times 1 B A^{2} \quad R^{2}=0.98$

- $(B) R V\left(\mathrm{~cm}^{3}\right) \hat{y}=0.00059+0.00355^{(p<0.01)} \times I B A-0.0025^{(p<0.01)} \times I B A^{2} \quad R^{2}=0.90$

(C) $\operatorname{SDM}(g) \hat{y}=0.6131+2.2705^{(p<001)} \times I B A-1.5204^{(p<001)} \times I B A^{2} \quad R^{2}=0.90$

- (D) $R D M(g) \quad \hat{y}=0.0950+0.3310^{(p<0.0 t)} \times I B A-0.1800^{(p=0.020)} \times I B A^{2} \quad R^{2}=0.71$

Figure 5 - Characteristics observed in seedlings of Eucalyptus urophylla $\mathrm{x}$ E. globulus clone in full sun in function of IBA concentrations $(0.0,0.25,0.5$, and 1.0 $\left.\mathrm{mg} \mathrm{L}^{-1}\right)$. (A) Number of roots; (B) Root volume $\left(\mathrm{cm}^{3}\right)$; (C) Shoot dry matter (g); and (D) Root dry matter $(\mathrm{g})$.

Figura 5 - Características observadas em pleno sol em mudas do clone de Eucalyptus urophylla $x$ E. globulus em função das doses de AIB (0,0;0,25;0,5 e 1,0 $\left.m g L^{-1}\right)$. (A) Número de raiz; (B) Volume de raiz $\left(\mathrm{cm}^{3}\right)$; (C) massa seca da parte aérea (g); e (D) massa seca da raiz ( $g$ ).

urophylla $\mathrm{x}$ E. globulus clone, regardless of the IBA concentration. Oliveira (2016) and Gómez et al. (2007) state that the variation of the multiplication rate is related to the in vitro conditions and consequently to the excessive exposure to growth regulators in the subcultures. It is also related to the balance of cytokinins and auxins in the culture medium since this balance varies depending on the species and explant type.

For all in vitro variables, an increasing trend was observed until the IBA concentration of $0.5 \mathrm{mg} \mathrm{L}^{-1}$. A decrease was observed from this value for Eucalyptus grandis $\mathrm{x}$ E. urophylla clone. This trend is explained for this is a rejuvenated material, in which the internal hormonal balance favors regeneration. Negative responses to additional hormonal applications may occur under certain conditions. Similar results were 
reported by Bezerra et al. (2014) for Mimosa caesalpiniifolia treated with BAP concentrations in in vitro multiplication. According to Hartmann et al. (2011), excessive concentrations of auxin and the exposure time to this growth regulator may inhibit shoots and roots development, causing yellowing and leaf fall, necrosis, and even plant death.

In the present work, the use of growth regulators was essential to achieve the desired multiplication rates. Auxin, such as IBA, and cytokinins, such as BAP, are used in several combinations for morphogenic control during adventitious shoots multiplication in Eucalyptus (Del Ponte et al., 2001; Dutra et al., 2009). Similar results were obtained using IBA in shoots of Eucalyptus globulus ssp. Maidenii, with a higher multiplication rate in culture medium containing $0.2 \mathrm{mg} \mathrm{L}^{-1} \mathrm{BAP}+0.02 \mathrm{mg} \mathrm{L}^{-1} \mathrm{IBA}$ (Sotelo and Monza, 2007).

Microcuttings production increased over the collections. No studies have reported on in vitro microcuttings production or elongated shoots in successive collections. However, this condition is analogous to the rejuvenation observed in plant materials that undergo several in vitro subcultures (Xavier et al., 2013). These are relevant results regarding the formation of in vitro microclonal hedge, and work as preliminary study for a mass and economic production of Eucalyptus microcuttings.

In addition, in the case of an ex vitro environment, microcuttings produced from microstump presents a cyclical trend and may be related to the temporary depletion of the latter, leading to lower productions (Titon et al., 2003b), besides the temperature change (Xavier and Comério, 1996).

The absence of IBA for both clones reduced growth, corroborating the work of Oliveira (2016), in which the absence of IBA provided lower growth rates for Eucalyptus urophylla $\mathrm{x}$ E. globulus clone and Eucalyptus grandis $\mathrm{x} E$. globulus clone. The best IBA concentration for Eucalyptus globulus ssp. maidenii elongation was 0.50 $\mathrm{mg} \mathrm{L}^{-1}$, resulting in four elongated shoots per explant $(>2 \mathrm{~cm}$ ) (Sotelo and Monza, 2007), which is in agreement with the present results. Different shoot length responses were observed by Oliveira (2016), with optimal IBA concentrations ranging from $0.25 \mathrm{mg} \mathrm{L}^{-1}$ to $1.0 \mathrm{mg} \mathrm{L}^{-1}$.

For both clones, shoots vigor reduced over the collections. This may have occurred due to the increase of the callus at the base of the in vitro explant. Callus is defined as a mass of disjointed and disorganized cells (Hartmann et al., 2011), which may have hindered the water and nutrients transport to the clump and reduced shoots vigor. Wendling et al. (2003) evaluated subculture of ministump and concluded that the subcultures did not increase ministumps vigor, evidencing a certain reduction trend with the increase in the subcultures.

Shoot vigor results in function of IBA concentrations were very different between the clones, evidencing genetic control for this variable. For Eucalyptus grandis x E. urophylla clone, the material that received the treatments with the intermediate concentration presented greater vigor. For Eucalyptus urophylla $\mathrm{x}$ E. globulus clone, the material that received the highest concentrations had the highest vigor; however, vigor decreased with the increase in the number of collections. Oliveira (2016) confirmed that the highest vigor for the tested Eucalyptus hybrid clones varied with the IBA concentrations between 0.36 and $0.80 \mathrm{mg} \mathrm{L}^{-1}$ in MS medium. In JADS culture medium, the maximum vigor points were higher at the IBA concentration of $0.60 \mathrm{mg} \mathrm{L}^{-1}$.

Evaluations under ex vitro environment conditions for Eucalyptus grandis x E. urophylla and Eucalyptus urophylla $\mathrm{x}$ E. globulus clones showed that treatments containing IBA in the culture medium influenced microcuttings quality. For the Eucalyptus grandis $\mathrm{x} E$. urophylla clone, the intermediate IBA concentrations applied in the in vitro environment provided the best results. For Eucalyptus urophylla x E. globulus clones, higher IBA concentrations presented satisfactory results; however, at some concentrations, the percentage of microcuttings rooting decreased. In some cases, the plant response to the endogenous or applied auxin may vary depending on the tissue and the IBA concentration already present in the propagule. In addition, auxin may increase the rhizogenic response to a certain point, depending on the concentration, after which inhibitory effect occurs (Hartmann et al., 2011).

For the present study, high mean percentage of survival was observed for both clones in the nursery, which makes feasible the proposed microcuttings technique. Studies with Bowdichia virgilioides (Moura et al., 2012), Aegiphila verticillata (Almeida et al., 2015), and Azadirachta indica (Houllou et al., 2015)

Revista Árvore. 2017;41(6):e410605 
have also presented high survival rates for in vitro microcuttings.

Further studies should be carried out to define the set of factors that influence micropropagation/ microcuttings of these Eucalyptus spp. clones or other genetic materials and hybrids of commercial interest, aiming to facilitate in vitro miniclonal hedges for seedlings production by the forestry industry.

\section{CONCLUSIONS}

For the clones evaluated in this study, results revealed that 1 ) the production of microcuttings for Eucalyptus grandis x E.urophylla and Eucalyptus urophylla $\mathrm{x}$ E. globulus clones increased over the five in vitro collections; 2) the IBA concentrations for each clone were adjusted, ranging from 0.25 to 0.50 $\mathrm{mg} \mathrm{L}^{-1}$ for Eucalyptus grandis $\mathrm{x}$ E.urophylla clone and from 0.75 to $1.0 \mathrm{mg} \mathrm{L}^{-1}$ for Eucalyptus urophylla $\mathrm{x}$ E. globulus clone; 3 ) the ex vitro conditions were influenced by the residual effect of the in vitro IBA concentrations; 4) IBA concentration between 0.25 and $0.50 \mathrm{mg} \mathrm{L}^{-1}$ and between 0.50 to $1.0 \mathrm{mg} \mathrm{L}^{-1}$ provided good rooting for Eucalyptus grandis x E.urophylla clone and Eucalyptus urophylla $\mathrm{x}$ E. globulus clone, respectively.

\section{ACKNOWLEDGMENTS}

The authors thank the Brazilian sponsoring agencies CNPq (Conselho Nacional de Desenvolvimento Científico e Tecnológico, Brazil), FAPEMIG (Fundação de Amparo à Pesquisa do Estado de Minas Gerais), and CAPES (Coordenação de Aperfeiçoamento de Pessoal de Ensino Superior) for the financial support; and BIOAGRO (Instituto de Biotecnologia Aplicada à Agropecuária) for the laboratory infrastructure.

\section{REFERENCES}

Almeida LMS, Morais LE, Resende CF, Braga VF, Pereira PF, Silva RAC et al. Micropropagation and aclimatization of Aegiphila verticillata Vell.: na andagered woody species. Revista Árvore. 2015;39:305-14.

Bezerra RMF, Aloufa MAI, Freire FAM, Santos DD. Efeito de 6-benzilaminopurina sobre a propagação in vitro de Mimosa caesalpiniifolia Benth. (Fabaceae). Revista Árvore. 2014;38:771-8.
Bisht P, Sharma VK, Joshi I, Kapoor ML. Micropropagation of newly produced F 1 hybrid of Eucalyptus (E. tereticornis Sm. $x$ E. camaldulensis Dehn. Southern Form). Silvae Genetica. 1999;48:104-8.

Bresinsky A, Körner C, Kadereit JW, Neuhaus G, Sonnenwald U. Tratado de botânica de Strasburger. $36^{\mathrm{a}}$ ed. Porto Alegre: Artmed; 2012. $1166 \mathrm{p}$.

Camargo SS, Rodrigues DB, Rodrigues CM, Assis AM, Faria RT, Schuch MW.

Fitorreguladores e espectros de luz na micropropagação de Oncidium baueri Lindl. Ciência Rural. 2015;45(11)2007-12.

Correia D, Gonçalves AN, Couto HZ, Ribeiro MC. Efeito do meio de cultura líquido e sólido no desenvolvimento de gemas de Eucalyptus grandis $\mathrm{x}$ Eucalyptus urophylla na multiplicação in vitro. IPEF. 1995(48/49):107-16.

Cunha ACMCM, Paiva HN, Leite HG, Barros NF, Leite FP. Influência do estado nutricional de minicepas no enraizamento de miniestacas de eucalipto. Revista Árvore. 2009a;33:607-15.

Cunha ACMCM, Paiva HN, Leite HG, Barros NF, Leite FP. Relações entre variáveis climáticas com produção e enraizamento de miniestacas de eucalipto. Revista Árvore. 2009b;33:195-203.

Cunha ACMCM, Wendling I, Souza Júnior L. Produtividade e sobrevivência de minicepas de Eucalyptus benthamii Maiden et Cambage em sistema de hidroponia e em tubete. Ciência Florestal. 2005;15:307-10.

Del Ponte EM, Mattei VL, Peters JA, Assis TF. Multiplicação e enraizamento in vitro de Eucalyptus globuluss ubsp. Globulus Labill. Revista Árvore. 2001;25:1-8.

Dutra LF, Wendling I, Brondani GE. A micropropagação de eucalipto. Pesquisa Florestal Brasileira. 2009;58:49-59.

Ferrari MP, Grossi F, Wendling I. Propagação vegetativa de espécies florestais. Colombo: Embrapa Florestas; 2004.

Ferreira EB, Cavalcanti PP, Nogueira DA. ExpDes: Experimental designs package. R

Revista Árvore. 2017;41(6):e410605 
package version 1.1.2. 2013.

Gómez C, Ríosa D, Sánchez-Olate M. Efecto del subcultivo sucesivo sobre lacaulo génesis adventicia de Eucalyptus globulus. Bosque. 2007;28:13-7.

Hartmann HT, Kester DE, Daves Jr FD, Geneve RL. Plant propagation: principles and practices. $8^{\text {th }}$ ed. New Jersey: Prentice-Hall; 2011.

Houllou LM, Souza RA, Santos ECP, Silva JJP, Barbosa MR, Sauvé JPG et al. Clonal propagation of nem (Azadirachta indica A. Juss.) via direct and indirect in vitro regeneration. Revista Árvore. 2015;39:439-45.

Iacona C, Muleo R. Light quality affects in vitro adventitious rooting and ex vitro performance of cherry rootstock colt. Scientia Horticulturae. 2010;125:630-6.

Joshi I, Bisht P, Sharma VK, Uniyal DP. In vitro clonal propagation of mature Eucalyptus F 1 hybrid (Eucalyptus tereticornis Sm. x E. grandis Hill ex. Maiden). Silvae Genetica. 2003;52(n.3/4):110-3.

Kerbauy GB. Fisiologia vegetal. $2^{\mathrm{a}}$ ed. Rio de Janeiro: Guanabara Koogan; 2012.

Kirdmanee C, Kitaya Y, Kozai T. Effects of $\mathrm{CO}_{2}$ enrichment and supporting material in vitro on photoautotrophic growth of Eucalyptus plantlets in vitro and ex vitro. In Vitro Cellular and Developmental Biology - Plant. 1995;31:144-9.

Kozai T. Photoautotrophic micropropagationenvironmental control for promoting photosynthesis. Propagation of Ornamental Plants. 2010;10:188-204.

Mafia RG, Alfenas AC, Ferreira EM, Zarpelon TG, Siqueira L. Crescimento de mudas e produtividade de minijardins clonais de eucalipto tratados com rizobactérias selecionadas. Revista Árvore. 2005;29:843-51.

Moura LC, Titon M, Fernandes JSC, Santana RC. Oliveira MLR. Micropropagação de sucupira preta por meio de gemas axilares. Pesquisa agropecuária brasileira. 2012;47(12):1691-8.
Oliveira LS, Xavier A, Lopes AP, Takahashi EK, Otoni WC. Multiplicação e alongamento in vitro de clones híbridos de Eucalyptus globulus. Ciência Florestal. 2016;26:235-47.

Oliveira ML, Xavier A, Penchel RM, Santos AFS. Multiplicação in vitro de Eucalyptus grandis x E. urophylla cultivado em meio semissólido e em biorreator de imersão temporária. Scientia Forestalis. 2011;39(91):309-15.

Oliveira ML, Xavier A, Penchel Filho RM, Reis JP. Efeito do intervalo de imersão e de injeção de ar na multiplicação in vitro de Eucalyptus grandis $\mathrm{x}$ Eucalyptus urophylla em biorreator de imersão temporária. Ciência Florestal. 2014;24:37-45.

Penchel RM, Otoni WC, Xavier A. Tecnologia de biorreatores e propagação in vitro. In: Borém A. editor. Biotecnologia florestal. Viçosa, MG: Universidade Federal de Viçosa, 2007. p.75-92.

R Core Team. R: A language and environment for statistical computing. R Foundation for Statistical Computing.Vienna. Disponível em: http://www.Rproject.org/. 2016.

Rossato M, Schumacher PV, Costa Netto APD, Souza GC, Reis EF, Stein VC. Multiplication and in vitro rooting of Campomanesia adamantium Camb. Plant Cell Culture \& Micropropagation. 2015;11(2)70-7.

Sotelo M, Monza J. Micropropagation of Eucalyptus maidenii elite trees. Agrociencia. 2007;9(6):81-9.

Taiz L, Zeiger E. Fisiologia vegetal. $5^{\text {a }}$ ed. Porto Alegre: Artmed; 2013.

Titon M, Xavier A, Otoni WC, Reis GG. Efeito do AIB no enraizamento de miniestacas e microestacas de Eucalyptus grandis W. Hill ex Maiden. Revista Árvore. 2003a;27:1-7.

Titon M, Xavier A, Reis GG, Otoni WC. Eficiência das minicepas e microcepas na produção de propágulos de clones de Eucalyptus grandis. Revista Árvore. 2003b;27:619-25.

Tronco KMDQ, Bisognin DA, Fleig FD, Horbach MA. Ex vitro rooting and acclimatization of Ilex paraguariensis A. St Hil. microcuttings. Cerne. 2015;21:371-8.

Revista Árvore. 2017;41(6):e410605 
Wendling I, Xavier A, Paiva HN. Influência da miniestaquia seriada no vigor de minicepas de clones de Eucalyptus grandis. Revista Árvore. 2003;27:611-8.

Xavier A, Comério J. Microestaquia: uma maximização da micropropagação de Eucalyptus. Revista Árvore. 1996;20:9-16.

Xavier A, Wendling I, Silva RL. Silvicultura clonal: princípios e técnicas. $2^{\mathrm{a}}$ ed. Viçosa, $\mathrm{MG}$ : Universidade Federal de Viçosa; 2013.

\section{ERRATA}

No artigo "IBA AND MICROCUTTING COLLECTIONS IN THE MICROPROPAGATION OF Eucalyptus spp HYBRID CLONES”, publicado no número 6, volume 41, da Revista Árvore, onde se lê:

\footnotetext{
${ }^{1}$ Received on 08.08.2014 accepted for publication on 26.09.2017.

${ }^{2}$ Universidade Federal de Viçosa, Programa de Pós-Graduação em Ciência Florestal,Viçosa, Minas Gerais, Brasil. E-mail: $<$ gallo.florestal@gmail.com>.

${ }^{3}$ Universidade Federal de Viçosa, Departamento de Engenharia Florestal, Viçosa, MG, Brasil . E-mail: <xavier@ufv.br>.

${ }^{4}$ Universidade Federal de Viçosa, Doutorado em Ciência Florestal, Viçosa, MG, Brasil and <lucianacm2005@yahoo.com.br>.

${ }^{5}$ Universidade Federal de Viçosa, Mestrado em Ciência Florestal, Viçosa, MG, Brasil. E-mail: < b.oliveiraefl@gmail.com>.

${ }^{6}$ Universidade Federal do Rio Grande do Norte, Unidade Acadêmica Especializada em Ciências Agraria, Macaíba, Brasil . E-mail: <gualtergcs@yahoo.com.br>.

${ }^{5}$ Universidade Federal de Viçosa, Programa de Pós-Graduação em Fitotecnia, Viçosa, MG, Brasil. E-mail: < helornasc@gmail.com>.

${ }^{7}$ Universidade Federal de Viçosa, Departamento de Biologia Vegetal, Viçosa, MG, Brasil . E-mail: <wcotoni@gmail.com>.
}

\section{L eia-s e:}

${ }^{1}$ Received on 08.08.2014 accepted for publication on 26.09.2017.

${ }^{2}$ Universidade Federal de Viçosa, Programa de Pós-Graduação em Ciência Florestal,Viçosa, Minas Gerais, Brasil. E-mail: <gallo.florestal@gmail.com>.

${ }^{3}$ Universidade Federal de Viçosa, Departamento de Engenharia Florestal, Viçosa, MG, Brasil. E-mail: <xavier@ufv.br>.

${ }^{4}$ Universidade Federal de Viçosa, Doutorado em Ciência Florestal, Viçosa, MG, Brasil.E-mail<lucianacm2005@yahoo.com.br>.

${ }^{5}$ Universidade Federal de Viçosa, Graduado em Ciência Florestal, Viçosa, MG, Brasil. E-mail: < b.oliveiraefl@gmail.com>.

${ }^{6}$ Universidade Federal de Viçosa, Programa de Pós-Graduação em Fitotecnia, Viçosa, MG, Brasil. E-mail: < helornasc@gmail.com>.

${ }^{7}$ Universidade Federal de Viçosa, Departamento de Biologia Vegetal, Viçosa, MG, Brasil . E-mail: <wcotoni@gmail.com>. 